УДК 37.022

\title{
ОБУЧЕНИЕ РИТОРИКЕ В СТАРШИХ КЛАССАХ
}

\author{
Хадашева Сабира Аюбовна \\ к.П.н., доцент \\ Хоцаонова Тамара Мусаевна \\ ФГБОУ ВО «Северо-Осетинский государственный \\ университет им. К.Л. Хетагурова»
}

\begin{abstract}
Аннотация: В статье речь идет об опыте обучения риторике в 9 классе. Это особенно актуально, так как им предстоит пройти устное собеседование по русскому языку в рамках сдачи ОГЭ. На основе обобщения своего опыта преподавания русского языка в школе авторы дают практические рекомендации по обучению риторике в старших классах. Статья составлена по итогам прохождения педагогической практики в школе, что обусловливает ее теоретическую и практическую ценность.
\end{abstract}

Ключевые слова: Риторика, речь, урок, выступление, методика обучения русскому языку.

\section{TEACHING RHETORIC IN THE HIGH SCHOOL}

\section{Khadasheva Sabira Ayubovna Khotsaonova Tamara Musaevna}

\begin{abstract}
The article deals with the experience of teaching rhetoric in the 9th grade. This is especially important, since they have to pass an oral interview in the Russian language as part of the OGE. On the basis of summarizing their experience in teaching Russian, the authors give practical recommendations for teaching rhetoric in high school. The article is based on the results of teaching practice at school, which determines its theoretical and practical value.
\end{abstract}

Key words: Rhetoric, speech, lesson, presentation, methods of teaching the Russian language.

Если задать вопрос - «В каких профессиях нужно умение говорить, выступать перед слушателями?». Можно услышать - в принципе, нужны во 
всех профессиях, такое умение полезно во всех случаях, работникам всех профессий, особенно руководящих, в том числе и учителям.

Умение правильно рассуждать необходимо как в обыденной повседневной жизни, так и на любом уроке в школе. Сегодня немыслима идеологическая работа для человека, не умеющего убедительно спорить, аргументировано отвечать на вопросы.

Хорошо говорить, в совершенстве владеть речью, свободно выступать перед слушателями, аудиторией - всему этому нас учит риторика, курс которой совсем недавно введен в учебный план на факультете осетинской филологии.

Во время прохождения педагогической практики в школе №50 г.Владикавказа нам еще раз пришлось встретиться с этим предметом риторику ввели как новую форму обучения. Дело в том, что многие ученики порой не могут четко изложить свою мысль, прочитать доклад, выступить перед классом. Мы часто говорим ученику, что в его ответе нет логической последовательности, а это одно из основных требований к ученику при устном собеседовании на ОГЭ по русскому языку, при написании изложений на ОГЭ и сочинений на ЕГЭ по русскому языку и риторика как раз призвана устранить эти недостатки.

И вот мы попробовали провести несколько уроков в 9 классах. На уроках риторики ребята узнали об античной риторике и ее теориях, выступили с сообщениями о выдающихся ораторах древности Демосфене, Цицероне и др. Большой интерес вызвала тема «Красноречие как орудие социальной борьбы». На уроках, посвященных этой теме, не только были осуществлены межпредметные связи (с историей, изобразительным искусством), но и показана роль риторики в наши дни.

Какие же задачи стояли перед школьниками: прежде всего, формирование навыков и умений владения материалом выступлений, средствами общения, классом, собой, своим поведением.

Первый урок - введение в предмет - знакомит ребят с его историей и перспективами овладения необходимыми навыками и умениями. Был проведен урок-спектакль, на котором учащиеся выступали в роли античных риторов. Учащиеся познакомились с классификацией красноречия в древности и в наши дни.

На следующих трех уроках лекционно излагались наиболее общие сведения о приемах подготовки и произнесения речи. Им были 
продемонстрированы образцы судебного и богословско-церковного красноречия, прослушаны видеозаписи примеров социально-политической, академической и бытовой речи, что позволило им осознать недостатки в их собственной манере изложения мыслей и научиться новым для них приемам риторики.

Одновременно с прослушиванием лекций ученики выполняли задания по подготовке небольших устных выступлений. Темы учащиеся выбирали по своему усмотрению, получив следующую рекомендацию: «Выбирайте тему, которая связана с вашим личным опытом, и по которой вы сможете в случае необходимости получить информацию в библиотеке или из других источников. Как правило, для первых выступлений ребята использовали «беспроигрышные», посвященные явлениям спорным, недостаточно изученным (например, о ясновидении, астрологии и т.д.). Неизученность таких тем позволила строить изложения на различных, иногда прямо противоположных, мнениях, что придавало выступлениям проблемность. После выступлений слушатели задавали вопросы по содержанию, часто возникали спонтанные дискуссии, что создавало обстановку живого общения, необходимого для развития речи. После этого ученики оценивали выступления друг друга по следующим критериям:

1. Интересна ли тема для данной аудитории, подходит ли она докладчику?

2. Свободно ли выступающий владел материалом?

3. Был ли контакт с аудиторией, чем это объясняется?

4. Владеет ли выступающий техникой речи?

5. Общее впечатление от выступления (и т.д.).

Работа над оценкой выступлений продолжалась из урока в урок, что давало возможность сформировать культуру дискуссий, так как ученики учатся выявлять не только недостатки, но и что значительно труднее подмечать положительное, смягчать отрицательные оценки, критиковать в доброжелательном тоне, проявляя такт, высказывать пожелания.

Подобные выступления прослушивались на каждом уроке (для этого выделялось 20-25 минут). Каждый ученик имел возможность выступить с сообщением, а также поучаствовать в дискуссии по содержанию, выступить с оценочным высказыванием.

Большую помощь ребятам оказали уроки на тему «Содержание и форма красноречия». Единство содержания и формы - главная мысль, которую они 
усвоили. Готовя свои устные выступления, учащиеся помнили, что содержанием выступления может быть только общественно-значимый вопрос или научная проблема, что построить ее надо логически правильно, по определенному плану и, произнося речь, надо помнить о единстве содержания и формы, о культуре речи. Была проведена большая работа по привитию культуры речи учащимся. Осуществлялась тесная связь с уроками русского языка и литературы. Регулярно проводилась работа над речевыми ошибками учащихся в письменной и устной речи. Параллельно шло обогащение словаря, работа с различными видами словарей. Этот вид работы чрезвычайно важен, так как прививает навыки работы с научной литературой, учит правилам использования справочного материала, что совершенно необходимо при современном уровне информации. Было и задание такого рода: из трех иллюстраций на тему «Золотая осень» надо выбрать одну и описать ее так, чтобы учащиеся отгадали ее. Ученики смогли настолько точно подобрать слова, используя художественные и эстетические элементы речи, что без труда можно было определить, какую иллюстрацию они использовали.

Нами также была предложена викторина «Отгадай литературного героя», где ученики продемонстрировали не только свои читательские вкусы, но и умение пользоваться словом. Не называя имени литературного героя, они так описали его внешность, что их товарищи без особого труда отгадали этого персонажа.

Было много и других интересных уроков, самым важным результатом которых явилось то, что у учащихся появилось бережное отношение к слову, интерес к русскому языку, стремление сделать свою речь более яркой и эмоциональной. Недаром эпиграфом к нашим урокам стали слова И.А.Бунина:

И нет у нас другого достоянья!

Умейте же беречь

Хоть в меру сил, в дни

Злобы и страданья

Наш дар бессмертный - речь.

Итак, занятия риторикой дали положительные результаты. Опросмнение учащихся в начале урока и в конце его показал, что уроки риторики им нужны. И психологически, и по уровню образования и развития речи они готовы к ним. В классах заметно повысился уровень познавательного интереса учащихся, получили развитие такие формы мыслительного процесса, как способность дифференцировать, обобщать, делать выводы, формировать 
оригинальные суждения. Кроме того, старшеклассникам удалось преодолеть трудности, связанные с управлением своим поведением, в аудитории во время выступлений, они стали увереннее в себе, научились справляться с волнением в ответственных ситуациях, менее скованной стала речь. Они научились отбирать и структурировать материал, композиционно его оформлять в расчете на восприятие слушателей.

\section{Список литературы}

1. Пасечная, И.Н. Культура речи (аспекты порождения высказывания) [Электронный ресурс]: практикум / С.В. Скоморохова, С.В. Юртаев, Оренбург. гос. ун-т, И.Н. Пасечная .- 3-е изд., стер. - М.: ФЛИНТА, 2019.$143 \mathrm{c}$. 